
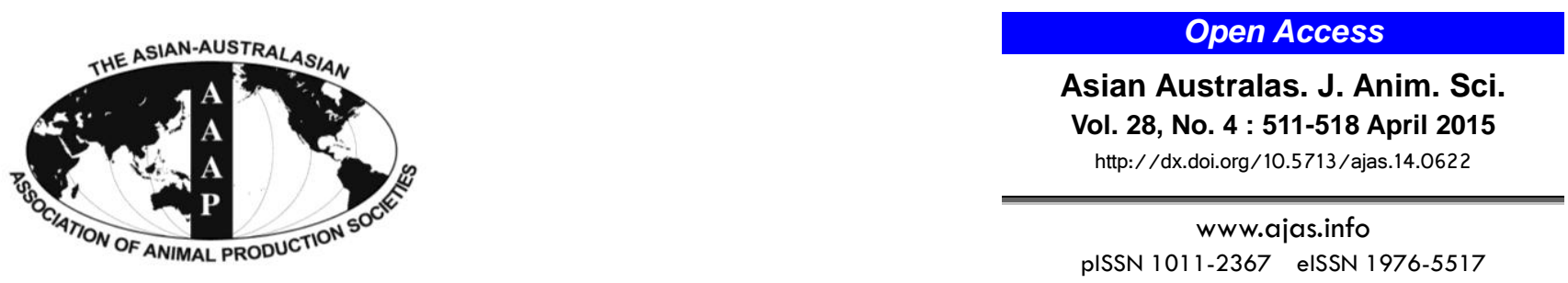

\title{
Fermentation Characteristics and Microbial Diversity of Tropical Grass-legumes Silages
}

\author{
Roni Ridwan $^{1,2, *}$, Iman Rusmana ${ }^{3}$, Yantyati Widyastuti², Komang G. Wiryawan ${ }^{4}$, \\ Bambang Prasetya ${ }^{2}$, Mitsuo Sakamoto ${ }^{5}$, and Moriya Ohkuma ${ }^{5}$ \\ ${ }^{1}$ Study Program of Microbiology, Graduate School of Bogor Agricultural University, \\ Campus IPB Darmaga Bogor, West Java 16680, Indonesia
}

\begin{abstract}
Calliandra calothyrsus preserved in silage is an alternative method for improving the crude protein content of feeds for sustainable ruminant production. The aim of this research was to evaluate the quality of silage which contained different levels of $C$. calothyrsus by examining the fermentation characteristics and microbial diversity. Silage was made in a completely randomized design consisting of five treatments with three replications i.e.: R0, Pennisetum purpureum $100 \%$; R1, P. purpureum $75 \%+$ C. calothyrsus $25 \%$; $\mathrm{R} 2$, P. purpureum $50 \%+$ C. calothyrsus $50 \%$; R3, P. purpureum $25 \%+$. calothyrsus $75 \%$; and R4, C. calothyrsus $100 \%$. All silages were prepared using plastic jar silos $(600 \mathrm{~g})$ and incubated at room temperature for 30 days. Silages were analyzed for fermentation characteristics and microbial diversity. Increased levels of $C$. calothyrsus in silage had a significant effect $(\mathrm{p}<0.01)$ on the fermentation characteristics. The microbial diversity index decreased and activity was inhibited with increasing levels of $C$. calothyrsus. The microbial community indicated that there was a population of Lactobacillus plantarum, L. casei, L. brevis, Lactococcus lactis, Chryseobacterium sp., and uncultured bacteria. The result confirmed that silage with a combination of grass and $C$. calothyrsus had good fermentation characteristics and microbial communities were dominated by L. plantarum. (Key Words: Calliandra calothyrsus, Silage, Fermentation Characteristics, Diversity, Lactobacillus plantarum)
\end{abstract}

\section{INTRODUCTION}

Calliandra calothyrsus is a tropical legume used for ruminant feed, which contains $17 \%$ to $30 \%$ crude protein (CP), (Norton, 1994; Hess et al., 2006; Jayanegara et al., 2011a). Crude protein supplies $\mathrm{N}$ for microbial protein

\footnotetext{
* Corresponding Author: Roni Ridwan. Tel: +62-21-8754587, Fax: +62-21-8754588, E-mail: roni001@ @ipi.go.id

${ }^{2}$ Research Center for Biotechnology, Indonesian Institute of Sciences, Cibinong, West Java 16911, Indonesia.

3 Department of Biology, Faculty of Mathematics and Natural Sciences, Bogor Agricultural University, Campus IPB Darmaga Bogor, West Java 16680, Indonesia.

${ }^{4}$ Department of Animal Nutrition and Feed Technology, Faculty of Animal Sciences, Bogor Agricultural University, Campus IPB Darmaga Bogor, West Java 16680, Indonesia.

${ }^{5}$ Microbe Division/ Japan Collection of Microorganisms RIKEN BioResource Center, Tsukuba, Ibaraki 305-0074, Japan.

Submitted Aug. 15, 2014; Revised Sept. 24, 2014; Accepted Nov. 6, 2014
}

synthesis in the rumen. Protein deficiency is the most common factor that leads to poor performance in ruminants, due to the animals being fed forages of low quality (Hess et al., 2006). Feed with a high protein content such as $C$. calothyrsus should be preserved using suitable methods; the method used depends on geographical location. Recently, for tropical regions, including Indonesia, silage has been used as a method for preserving forages. Ensiling is a natural fermentation process where lactic acid bacteria (LAB) convert water soluble carbohydrates (WSC) into organic acids, mainly lactic acid (McDonald et al., 1991; Lynch et al., 2012). The dominance of homofermentative LAB is preferable, as rapid acidification occurs, which decreases $\mathrm{pH}$ to inhibit the growth of undesirable microorganisms and reduces nutritional loss in the ensiling process (McDonald et al., 1991).

The other benefit of $C$. calothyrsus is its tannin concentration of approximately $8.1 \%$ may reduce enteric 
$\mathrm{CH}_{4}$ (Jayanegara et al., 2011a). Feed containing tannin seems promising as a nutritional strategy to reduce $\mathrm{CH}_{4}$ emissions from ruminants in the tropics (Tiemann et al., 2008). The $\mathrm{CH}_{4}$ is a potent greenhouse gas that contributes to global warming (Bodas et al., 2012; Patra et al., 2012), and enteric rumen fermentation contributes to atmospheric pollution (Moss et al., 2000).

However, legumes that have a low WSC content and high buffer capacity do not produce good quality silage (McDonald et al., 1991; Norton, 1994). Combination grasses and legumes are an alternative solution to the success of the ensiling process. Successful ensiling can be evaluated by determining the relationships between fermentation characteristics and microbial diversity in silages. Fermentation product and microbial community during ensiling in several types of ruminant forages has been reported by $\mathrm{Li}$ and Nishino (2013), but information about tropical forages, especially C. calothyrsus, is still limited. Analysis of the microbial community based on $16 \mathrm{~S}$ rDNA is suitable for characterizing microbial diversity (Liu et al., 1997; Kaplan et al., 2001). The objective of this research was to evaluate the quality of silage containing different levels of $C$. calothyrsus by assessing fermentation characteristics and microbial diversity.

\section{MATERIALS AND METHODS}

\section{Ensiling}

Silage was made using wilted king grasses (Pennisetum purpureum hybrid) and $C$. calothyrsus (Fabaceae; red flower) legumes. The grasses were provided by the Plant Collection of the Research Center for Biotechnology. Legumes were collected from the Agrostology Field Laboratory of Bogor Agricultural University. Grasses and legumes were chopped to lengths of approximately $5 \mathrm{~cm}$. Ready available carbohydrate (10\%) and inoculants of Lactobacillus plantarum BTCC570 $\left(2.5 \times 10^{6} \mathrm{cfu} / \mathrm{g}\right.$ material $)$ were used as silage additives. Silage was made with a completely randomized design, and consisted of five treatments with three replications i.e.: R0, P. purpureum 100\%; R1, P. purpureum $75 \%+C$. calothyrsus $25 \%$, R2, P. purpureum $50 \%+C$. calothyrsus $50 \%$, R3, P. purpureum $25 \%+C$. calothyrsus $75 \%$, and $\mathrm{R} 4, C$. calothyrsus $100 \%$. All silages were prepared using plastic jar silos to laboratory scale $(600 \mathrm{~g})$ and then incubated at room temperature $\left( \pm 30^{\circ} \mathrm{C}\right)$ for 30 days.

\section{Silage sample preparation}

After 30 days, silages were opened and divided into two parts; one part was oven-dried and milled to pass through a 0.5 to $1 \mathrm{~mm}$ aperture sieve for proximate, fiber fraction, total phenol (TP), and total tannin (TT) analyses. The second part was used for the extraction of silage juice for detecting the $\mathrm{pH}$ and $\mathrm{LAB}$ population on the day of silo opening; the rest was stored at $-20^{\circ} \mathrm{C}$ for measuring the concentration of lactic acid, WSC, volatile fatty acids (VFA), ammonia nitrogen $\left(\mathrm{NH}_{3}-\mathrm{N}\right)$, and for microbial diversity analysis. Silage juice was made using a blender, with the addition of sterilized distilled water to the silage samples $(1: 1 \mathrm{w} / \mathrm{v})$; the juice was then filtered using sterilized double cheeseclothes and then placed into a 15 $\mathrm{mL}$ sterilized corning tube.

\section{Silage quality evaluation}

Raw material and silage samples were analyzed using the proximate standard procedures of AOAC (1997), and the fiber fraction content protocol by Van Soest et al. (1991). The CP and ether extract content (EE) were analyzed using FOSS equipment (Kjeltec 8400 analyzer unit and Soxtec 2050, Hoganas, Sweden). Neutral detergent fiber (NDF), acid detergent fiber (ADF), acid detergent lignin (ADL), hemicellulose, and cellulose were analyzed using Fibertec apparatus (FOSS Fibertec 2010, Hoganas, Sweden). Other parameters were also tested, including temperature, $\mathrm{pH}$ using Cyberscan pH310 Eutech, concentration of lactic acid by the titration method, $\mathrm{NH}_{3}-\mathrm{N}$ by the Conway method, WSC by a colorimetric method (Dubois et al., 1956), VFA using GC-FID (Bruker Scion 436, Fremont, CA, USA) and TP and TT by the Folin-Ciocalteu method (Makkar, 2003). The LAB population was determined by total plate count using MRS agar (Cappucino and Sherman, 2001). Microbial diversity was determined by terminal restriction length polymorphism (T-RFLP) analysis (Sakamoto et al., 2003; 2006).

\section{Terminal restriction length polymorphism analysis}

Microbial DNA from silage juice was extracted using a genomic DNA mini kit, which is based on the Buffy coat protocol (Geneaid) with some modifications, such as addition of proteinase $\mathrm{K}$ (final concentration of $2 \mathrm{mg} / \mathrm{mL}$ ) and RNase A (final concentration of $10 \mathrm{mg} / \mathrm{mL}$ ). DNA was then incubated at $60^{\circ} \mathrm{C}$ for $30 \mathrm{~min}$. Specimen DNA was pooled from each treatment (five DNA samples in total).

DNA was amplified using primer 6FAM-27F (5'AGAGTTTGATCCTGGCTCAG-3') and 1492R (5'GGTTACCTTGTTACGACTT-3'). The amplification of the polymerase chain reaction (PCR) reaction was performed as described previously (Sakamoto et al., 2006), with total volume of $50 \mu \mathrm{L}$ consisting of $5 \mu \mathrm{L}$ dissolved DNA $(<1 \mu \mathrm{g})$, $0.5 \mu \mathrm{L}$ of $1.25 \mathrm{U}$ Takara Ex Taq (Takara Shuzo Co., Shiga, Japan), $5 \mu \mathrm{L}$ of $10 \times$ Ex Taq buffer, $4 \mu \mathrm{L}$ of dNTP mixture (2.5 mM each) and $10 \mathrm{pmol}$ of each primer. 16S rDNA was amplified using a Biometra Thermocycler TGradient using the following program: $95^{\circ} \mathrm{C}$ for $3 \mathrm{~min}$, followed by 30 cycles consisting of $95^{\circ} \mathrm{C}$ for $30 \mathrm{~s}, 50^{\circ} \mathrm{C}$ for $30 \mathrm{~s}$ and $72^{\circ} \mathrm{C}$ for $1.5 \mathrm{~min}$, with a final extension at $72^{\circ} \mathrm{C}$ for $10 \mathrm{~min}$. 
Amplified DNA was verified by electrophoresis of the PCR product $(5 \mu \mathrm{L})$ using $1.5 \%$ agarose. PCR products were purified using an ultraclean PCR kit (Mo Bio Laboratories, Inc.) and then stored at $-20^{\circ} \mathrm{C}$ until analysis.

The T-RFLP was analyzed based on the method by Sakamoto et al. (2003), with some modifications. The purified PCR product $(2 \mu \mathrm{L})$ was digested with three restriction enzymes consisting of $20 \mathrm{U}$ of $A l u \mathrm{I}, M s p \mathrm{I}$, and RsaI (Takara Shuzo, Japan) in a total volume of $10 \mu \mathrm{L}$ at $37^{\circ} \mathrm{C}$ for $1 \mathrm{~h}$. The restriction digest product $(2 \mu \mathrm{L})$ was mixed with $8 \mu \mathrm{L}$ of Hi-Di Formamide and $1 \mu \mathrm{L}$ of standard Gene Scan 1200 LIZ (Applied Biosystems, Foster City, CA, USA). Each sample was denatured at $95^{\circ} \mathrm{C}$ for $2 \mathrm{~min}$ and then immediately placed on ice. The length of T-RF was determined using an ABI PRISM 3100 Genetic Analyzer (Applied Biosystems, USA). T-RFs were estimated by using local method peak scan version 2.0 (Applied Biosystems, USA). T-RFs with an area peak of less than $2 \%$ of the total area were excluded from the analysis (Sakamoto et al., 2003; 2006). DNA fragments were resolved to one base pair by manual alignment of the standard peaks from different electrophoretograms. Prediction of T-RFs was performed by using the MiCAIII microbial diversity database (Shyu et al., 2007). Phylogenetic relationships were determined from predicted T-RFs using the DDBJ and RDP II databases (Cole et al., 2009). Dendrogram analysis was based on the similarity coefficient for the objective interpretation of the difference of T-RF patterns using the unweighted pair-group method with arithmetic mean (UPGMA) (Blackwood et al., 2003). Diversity of microbial populations was determined based on the Shannon index method, as previously described by Magurran (2004).

\section{Statistical analysis}

Data of fermentation characteristics were analyzed using analysis of variance with SPSS 16 for Microsoft Windows. Significant effects of treatments were further analyzed using the least significant differences Duncan's
Table 1. Chemical composition of raw materials

\begin{tabular}{lccc}
\hline Composition & $\begin{array}{c}P . \\
\text { purpureum }\end{array}$ & $\begin{array}{c}\text { Calothyrsus } \\
\text { can }\end{array}$ & RAC \\
\hline Dry matter (DM) (g/kg) & 312.5 & 450.5 & 853.1 \\
Organic matter (g/kg DM) & 895.5 & 947.9 & 845.1 \\
Crude protein (g/kg DM) & 45.2 & 212.1 & 93.5 \\
Ether extract (g/kg DM) & 4.7 & 19.0 & 41.7 \\
Neutral detergent fiber & 746.2 & 551.8 & 382.8 \\
$\quad(g / k g$ DM) & & & \\
Acid detergent fiber & 510.1 & 488.8 & 268.0 \\
$\quad(g / k g$ DM) & & & \\
Acid detergent lignin & 382.5 & 215.7 & 140.6 \\
$\quad(g / k g$ DM) & & & \\
Hemicellulose (g/kg DM) & 236.2 & 63.0 & 114.8 \\
Cellulose (g/kg DM) & 73.5 & 299.8 & 100.5 \\
Total phenols (g/kg DM) & 36.0 & 165.4 & NA \\
Total tannin (g/kg DM) & 8.7 & 142.7 & NA \\
\hline
\end{tabular}

RAC, ready available carbohydrate; NA, not available.

Test $(\mathrm{p}<0.01)$; microbial diversity data were analyzed descriptively.

\section{RESULTS}

\section{Fermentation characteristics}

Chemical and nutrient compositions of the raw materials and silage samples are shown in Table 1 and 2 . Inclusion of different levels of $C$. calothyrsus significantly increased $(p<0.01)$ the contents of dry matter $(D M)$, organic matter, $\mathrm{CP}$, and EE of the silages. The silages varied in DM content. DM of R0 was lower $(\mathrm{p}<0.01)$ than R2, R3, and R4. The content of CP in R0 was the lowest and significantly different $(p<0.01)$ compared to the other treatments. Meanwhile, the content of the fibrous fractions of each silage varied among treatments. The NDF, ADF, ADL, and hemicellulose contents were consistently decreased with increasing levels of $C$. calothyrsus except for cellulose. The cellulose content of R0 silage was the lowest $(\mathrm{p}<0.01)$

Table 2. Nutrient composition and fiber fraction of silages

\begin{tabular}{|c|c|c|c|c|c|}
\hline \multirow{2}{*}{ Composition } & \multicolumn{5}{|c|}{ Treatment $^{1}$} \\
\hline & R0 & R1 & R2 & R3 & $\mathrm{R} 4$ \\
\hline$\overline{\text { Dry matter }(\mathrm{DM})(\mathrm{g} / \mathrm{kg})}$ & $311.9^{\mathrm{a}}$ & $335.5^{\mathrm{ab}}$ & $369.7^{\mathrm{bc}}$ & $407.1^{\mathrm{c}}$ & $465.4^{\mathrm{d}}$ \\
\hline Organic matter (g/kg DM) & $875.0^{\mathrm{a}}$ & $897.0^{\mathrm{b}}$ & $909.4^{\mathrm{bc}}$ & $923.8^{\mathrm{cd}}$ & $934.0^{\mathrm{d}}$ \\
\hline Crude protein (g/kg DM) & $56.0^{\mathrm{a}}$ & $105.7^{\mathrm{b}}$ & $142.5^{\mathrm{c}}$ & $172.6^{\mathrm{d}}$ & $202.2^{\mathrm{e}}$ \\
\hline Ether extract (g/kg DM) & $16.1^{\mathrm{a}}$ & $13.0^{\mathrm{a}}$ & $27.9^{\mathrm{b}}$ & $31.8^{\mathrm{bc}}$ & $34.5^{\mathrm{c}}$ \\
\hline Neutral detergent fiber (g/kg DM) & $665.8^{\mathrm{c}}$ & $597.0^{\mathrm{b}}$ & $559.6^{\mathrm{a}}$ & $544.1^{\mathrm{a}}$ & $538.4^{\mathrm{a}}$ \\
\hline Acid detergent fiber (g/kg DM) & $492.1^{\mathrm{b}}$ & $452.7^{\mathrm{a}}$ & $446.1^{\mathrm{a}}$ & $447.3^{\mathrm{a}}$ & $448.8^{\mathrm{a}}$ \\
\hline Acid detergent lignin (g/kg DM) & $343.6^{\mathrm{d}}$ & $253.8^{\mathrm{c}}$ & $261.5^{\mathrm{c}}$ & $174.6^{\mathrm{b}}$ & $134.1^{\mathrm{a}}$ \\
\hline Hemicellulose (g/kg DM) & $173.7^{\mathrm{d}}$ & $144.4^{\mathrm{c}}$ & $113.5^{\mathrm{b}}$ & $96.8^{\mathrm{ab}}$ & $89.6^{\mathrm{a}}$ \\
\hline Cellulose (g/kg DM) & $87.9^{\mathrm{a}}$ & $157.0^{\mathrm{b}}$ & $150.5^{\mathrm{b}}$ & $254.6^{\mathrm{c}}$ & $307.0^{\mathrm{d}}$ \\
\hline
\end{tabular}

${ }^{1}$ R0, P. purpureum 100\%; R1, P. purpureum 75\%+C. calothyrsus 25\%; R2, P. purpureum 50\%+C. calothyrsus 50\%; R3, P. purpureum $25 \%+C$. calothyrsus $75 \%$; and R4, C. calothyrsus $100 \%$.

${ }^{\mathrm{a}-\mathrm{e}}$ Values with different superscripts are significantly different from each other $(\mathrm{p}<0.01)$. 
Table 3. Fermentation characteristics of silage

\begin{tabular}{lccccc}
\hline \multirow{2}{*}{ Characteristics } & \multicolumn{5}{c}{ Treatment $^{1}$} \\
\cline { 2 - 6 } & $\mathrm{R} 0$ & $\mathrm{R} 1$ & $\mathrm{R} 2$ & $\mathrm{R} 3$ & $\mathrm{R} 4$ \\
\hline Temperature $\left({ }^{\circ} \mathrm{C}\right)$ & $28.53^{\mathrm{a}}$ & $28.87^{\mathrm{a}}$ & $29.03^{\mathrm{ab}}$ & $29.50^{\mathrm{bc}}$ & $29.90^{\mathrm{c}}$ \\
$\mathrm{pH}$ & $3.52^{\mathrm{a}}$ & $3.51^{\mathrm{a}}$ & $3.65^{\mathrm{ab}}$ & $3.84^{\mathrm{bc}}$ & $4.00^{\mathrm{c}}$ \\
$\mathrm{LAB}(\log \mathrm{cfu} / \mathrm{g})$ & $5.40^{\mathrm{a}}$ & $6.49^{\mathrm{bc}}$ & $5.93^{\mathrm{ab}}$ & $6.74^{\mathrm{bc}}$ & $7.28^{\mathrm{c}}$ \\
$\mathrm{NH}_{3}-\mathrm{N}(\mathrm{mM} / \mathrm{g}$ DM) & $13.93^{\mathrm{a}}$ & $21.68^{\mathrm{a}}$ & $34.09^{\mathrm{b}}$ & $42.21^{\mathrm{b}}$ & $43.56^{\mathrm{b}}$ \\
$\mathrm{WSC}(\mathrm{g} / \mathrm{kg} \mathrm{DM})$ & 24.09 & 21.60 & 17.06 & 17.40 & 17.99 \\
Lactic acid $(\mathrm{g} / \mathrm{kg} \mathrm{DM})$ & $32.8^{\mathrm{b}}$ & $29.8^{\mathrm{ab}}$ & $28.7^{\mathrm{ab}}$ & $22.9^{\mathrm{a}}$ & $20.4^{\mathrm{a}}$ \\
Acetic acid $(\mathrm{g} / \mathrm{kg} \mathrm{DM})$ & 6.26 & 5.31 & 5.68 & 5.38 & 5.85 \\
Propionic acid $(\mathrm{g} / \mathrm{kg} \mathrm{DM})$ & 0.23 & 0.13 & 0.58 & 0.95 & 0.15 \\
Butyric acid $(\mathrm{g} / \mathrm{kg} \mathrm{DM})$ & 0.77 & 0.71 & 0.66 & 0.60 & 0.38 \\
Total phenols $(\mathrm{g} / \mathrm{kg} \mathrm{DM})$ & $45.3^{\mathrm{a}}$ & $75.0^{\mathrm{b}}$ & $71.1^{\mathrm{ab}}$ & $87.2^{\mathrm{b}}$ & $94.1^{\mathrm{b}}$ \\
Total tannin $(\mathrm{g} / \mathrm{kg} \mathrm{DM})$ & $14.0^{\mathrm{a}}$ & $39.2^{\mathrm{b}}$ & $48.3^{\mathrm{bc}}$ & $61.1^{\mathrm{c}}$ & $69.2^{\mathrm{c}}$ \\
\hline
\end{tabular}

DM, dry matter; LAB, lactic acid bacteria; WSC, Water soluble carbohydrates.

${ }^{1}$ R0, P. purpureum $100 \%$; R1, P. purpureum $75 \%+$ C. calothyrsus $25 \%$; $\mathrm{R} 2$, P. purpureum $50 \%+C$. calothyrsus $50 \%$; R3, P. purpureum $25 \%+C$. calothyrsus $75 \%$; and R4, C. calothyrsus $100 \%$.

${ }^{a-c}$ Values with different superscripts are significantly different from each other $(\mathrm{p}<0.01)$.

compared to all of the other treatments. The effect of the inclusion of $C$. calothyrsus in silage on fermentation characteristics is presented in Table 3. The temperature, $\mathrm{pH}$, LAB population, $\mathrm{NH}_{3}-\mathrm{N}, \mathrm{TP}$, and TT all increased $(\mathrm{p}<0.01)$ significantly as the level of $C$. calothyrsus increased. Lactic acid concentration did not increase; silage with higher levels of $C$. calothyrsus had reduced lactic acid concentration compared to those containing lower levels of C. calothyrsus. The increase in the level of $C$. calothyrsus
Table 4. Microbial diversity index in silage

\begin{tabular}{lccc}
\hline \multirow{2}{*}{ Index value } & \multicolumn{3}{c}{ Treatment $^{1}$} \\
\cline { 2 - 4 } & $\mathrm{R} 0$ & $\mathrm{R} 2$ & $\mathrm{R} 3$ \\
\hline Richness $(S)$ & $7( \pm 3)$ & $3( \pm 0.58)$ & $3( \pm 1.15)$ \\
Shannon $\left(H^{\prime}\right)$ & $2.07( \pm 0.93)$ & $0.88( \pm 0.21)$ & $0.65( \pm 0.51)$ \\
\hline
\end{tabular}

${ }^{1}$ R0, P. purpureum $100 \%$; R2, P. purpureum $50 \%+$ C. calothyrsus $50 \%$; and $\mathrm{R} 3, P$. purpureum $25 \%+C$. calothyrsus $75 \%$.

had tendency to reduce the content of WSC and butyric acid on a DM basis.

\section{Microbial diversity in silage}

A total of five samples were subjected to PCR with $16 \mathrm{~S}$ rDNA universal primers but 16S rDNA could not be amplified from two samples (R1 and R4). The PCR products obtained from the two samples were not suitable for T-RFLP analysis due to weak amplification. Consequently, three samples were subjected to T-RFLP analysis. The microbial diversity calculated by the Shannon index varied among treatments and a decrease was observed in the bacterial population diversity as levels of $C$. calothyrsus increased (Table 4). The increase of the diversity index in silage indicated that each sample contained diverse populations of microorganisms. Sample R0 showed the highest value of T-RF richness and Shannon index compared to the other treatments, while R3 had the lowest Shannon index.

The close similarity of microorganisms in silage was confirmed by the dendrogram (Figure 1a and 1b). It was constructed by combining three T-RFLP patterns with three

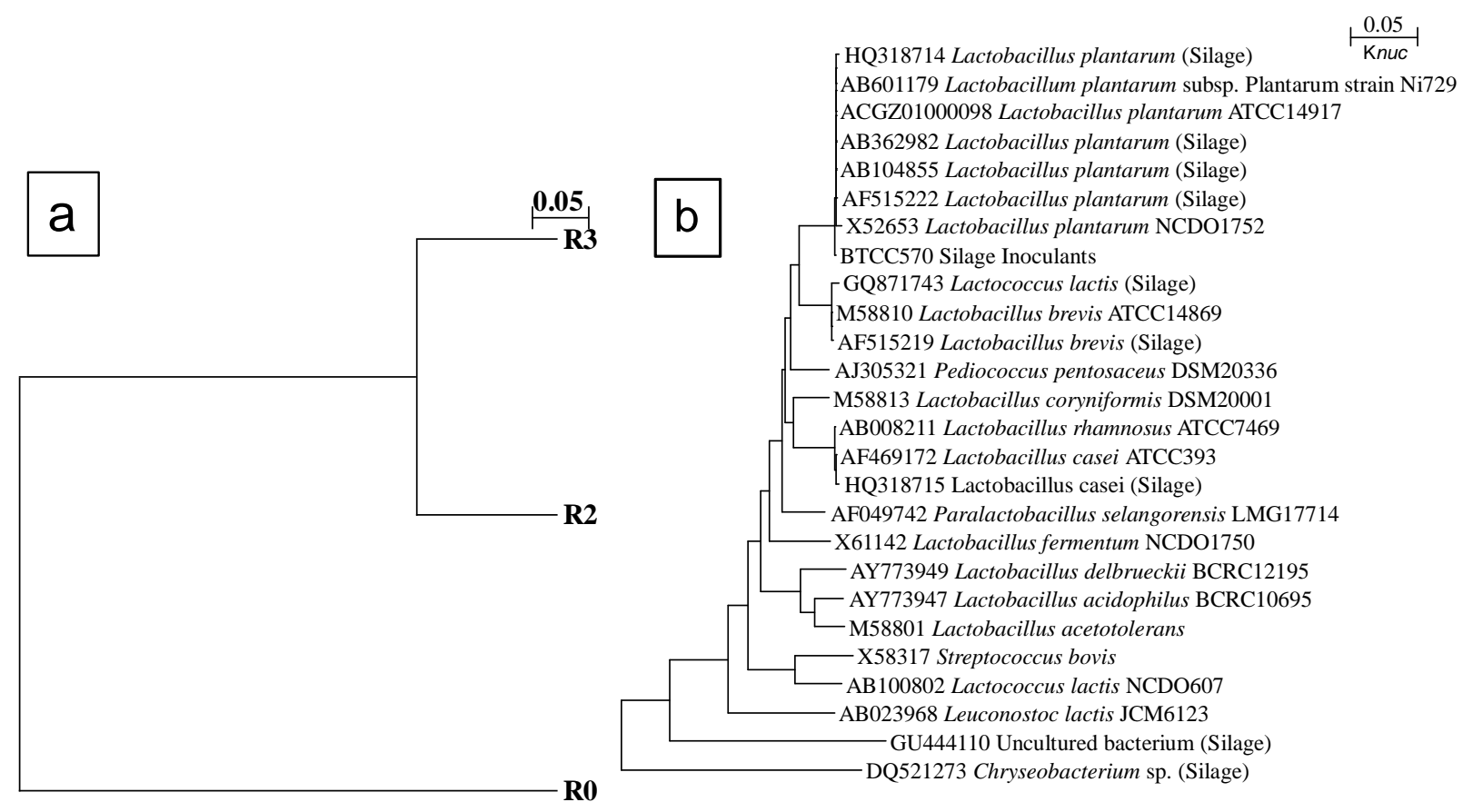

Figure 1. Close similarity of silage microbial (a) and phylogenetic relationship (b). R0, P. purpureum $100 \%$; R2, P. purpureum $50 \%+C$. calothyrsus $50 \%$; and R3 P. purpureum $25 \%+$ C. calothyrsus $75 \%$. 
different restriction enzymes by UPGMA methods (Figure 1a). Samples R2 and R3 were shown to have similar microorganisms. The phylogenetic tree was constructed by alignment of the T-RF database from DDBJ and RDP II type strains (Figure 1b). It described T-RFs of each silage treatment which showed close similarity with the other database. T-RFs from silage treatments were predicted to high similarity compared with the MiCAIII database. Figure 2 shows the changes in microbial diversity of silage with different levels of $C$. calothyrsus. The microbial community analysis clarified by T-RFLP indicated that there was a population of four LAB phylotypes, Chryseobacterium sp., and uncultured bacteria (Figure 2). Microorganisms in the silage were dominated by LAB. The LAB population had close similarity with $L$. plantarum, $L$. casei, L. brevis, and Lactococcus lactis.

\section{DISCUSSION}

The combination of grasses and legumes in ruminant feed is very effective for a highly nutritional diet (Steurm et al., 2007). The purpose of the addition of legumes to silage is to supply N-protein for microbial protein synthesis, reduce protein degradation in the rumen, and increase amino acid absorption in the intestinal tract. GómezVázquez et al. (2011) and Wanapat et al. (2014) expressed that silages can be used for alternative feed supplement to improve ruminant performance. The feed containing the highly nutritive grass-legume combination generally needs to be preserved for a long time. A pH of less than 4 can be used to preserve feed for a long period, which reflects the adequacy of fermentation to restrict the growth of undesirable microorganisms (Arriola et al., 2011). McDonald et al. (1991) described that the characteristics of good silage should have $\mathrm{pH}$ values of 4.20 or less, $\mathrm{NH}_{3}-\mathrm{N}$ contents less than $100 \mathrm{~g} / \mathrm{kg} \mathrm{DM}$, and high lactic acid contents. In this study, all silages were well-preserved, with high lactic acid contents and low $\mathrm{pH}$ values (Table 3 ). During the ensilage process, LAB produced lactic acid to lower the $\mathrm{pH}$ and inhibit the growth of undesirable microorganisms, and produced good quality silage. The silage from sample R2 had adequate silage nutritional values based on the standard requirements of ruminant feed.

There was a unique relationship between silage fermentation characteristics and microbial diversity; $\mathrm{pH}$, LAB, and TT increased, but lactic acid decreased with

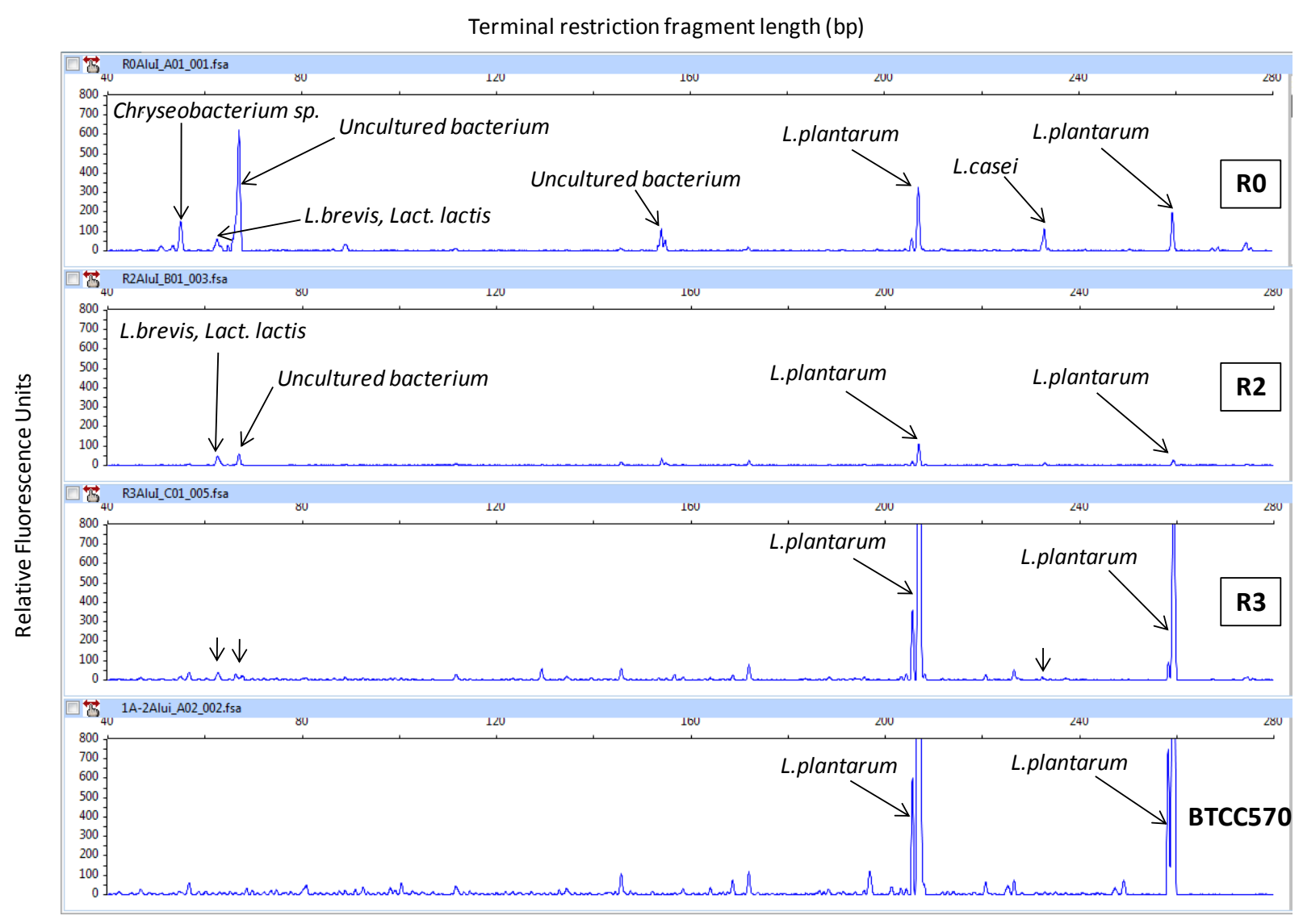

Figure 2. T-RFLP patterns of silage and L. plantarum BTCC570 after digestion with restriction enzyme AluI. R0, P. purpureum 100\%; $\mathrm{R} 2$, P. purpureum $50 \%+C$. calothyrsus $50 \%$; and R3, P. purpureum $25 \%+C$. calothyrsus $75 \%$. T-RFLP, terminal restriction length polymorphism. 
increasing levels of the legume (Table 3). The increasing LAB population generally increases lactic acid concentration, but in this study the opposite was observed. This finding suggests that legumes used had low WSC and that TT inhibited lactic acid production of LAB. Norton (1994) and McDonald et al. (1991) stated that legumes are generally high in protein content and buffering capacity, but low in WSC content. The high level of tannins used can also reduce the activities of silage bacteria (Salawu et al., 1999). Both TP and TT contents contributed to the decrease in lactic acid production. These results agree with those from Deaville et al. (2010) who found that tannin suppressed the production of lactic acid during ensilage. In this case, lower TT in sample R0 produced higher lactic acid compared to the other treatments (Table 3 ). Sonja et al. (2012) reported that low $\mathrm{pH}$ and anaerobic conditions reduced TT content. The TT content of silage decreased $51.5 \%$ in R4 after 30 days incubation. A high concentration of polyphenolics such as TT in the feed can inhibit digestibility, absorption and reduce $\mathrm{CH}_{4}$ production. Enteric $\mathrm{CH}_{4}$ production in rumen fermentation has been intensively studied, and the beneficial effect of tannin to reduce $\mathrm{CH}_{4}$ emission and gas production has also been reported by several authors (Castro-Montoya et al., 2011; Jayanegara et al., 2011a, b; Bodas et al., 2012; Kondo et al., 2014). Jayanegara et al. (2011b) reported that TT can be used at a concentration of less than $100 \mathrm{~g} / \mathrm{kg} \mathrm{DM}$, which is equivalent to $10 \% \mathrm{DM}$ in the feed formulation for cattle.

Generally, the first stage of ensiling is competition among the epiphytic microorganisms to use WSC to produce fermentation products. Undesirable microorganisms such as enterobacteria, clostridia, and fungi also grow in the silage, causing nutritional losses. $\mathrm{Li}$ and Nishino (2013) reported that several non-LAB bacteria such as Pantoea agglomerans and Enterobacter sp. were found in the pre-ensiled Italian ryegrass. Chryseobacterium sp., and uncultured bacteria were detected in R0 tendency to produce high contents of acetic acid and butyric acid (Figure 2, Table 3). The methods for inhibiting the growth of undesirable microorganisms include the addition of LAB inoculants, substitution with other materials containing high $\mathrm{DM}$, such as legume, or reducing the moisture content of the crops (McDonald et al., 1991; Arriola et al., 2011). The purpose of LAB inoculants is to compete with the epiphytic microorganisms by increasing lactic acid production to inhibit undesirable microorganisms. The changes in microbial population in the first stage of the ensiling process are critical to the success of the fermentation process (Mulrooney and Kung, 2008).

In this research, silage was also made by using LAB inoculants to increase the $\mathrm{LAB}$ population, in order to stimulate lactic acid production, accelerate the decrease in $\mathrm{pH}$, and increase silage quality. Microbial diversity in the silage can determine the silage quality. The increasing level of $C$. calothyrsus in the silage decreased the microbial diversity index. The LAB has the potential to increase the production of lactic acid because it is homofermentative (McDonald et al., 1991; Lynch et al., 2012). This finding suggests that the L. plantarum population was sufficiently established during ensiling process and able to utilize the high concentration of $\mathrm{NH}_{3}-\mathrm{N}$. The $\mathrm{NH}_{3}-\mathrm{N}$ in the silage was used as a source of $\mathrm{N}$ for microbial protein synthesis, for microbial growth (McDonald et al., 1991; Norton, 1994). The growth of the L. plantarum population was resistant to tannin but its activity decreased with high levels of $C$. calothyrsus. The resistance mechanism may be correlated to the production of lactic acid. Patra et al. (2012) reported that heme-containing enzyme from Lactobacillus is not present and produce exo-polysaccharides that form the protective layer around the cell. This mechanism potentially inhibited the lactic acid production. Other known resistance mechanisms of L. plantarum include the ability to degrade phenolic compounds (Landete et al., 2008; Rodríguez et al., 2009) such as tannin, by the action of novel tannase (tanLpI) (Iwamoto et al., 2008) and gallate decarboxylase enzymes (lpdB and $l p d C$ ) (Jiménez et al., 2013). In the present study, the silage contained four homofermentative type $\mathrm{LAB}$, of which the most dominant was $L$. plantarum (Figure 2). Lynch et al. (2012) reported that the $L$. plantarum population in silage without or with the addition of the inoculants was more dominant than the population of L. buchneri. The population of $L$. plantarum was shown to be dominant in wilted guinea grass silage stored for 28 days, followed by $L$. brevis, L. lactis, Enterobacter sp., and $L$. garvieae (Li and Nishino, 2013).

\section{CONCLUSION}

Increasing levels of $C$. calothyrsus had a significant effect on the fermentation characteristics, such as the nutrient and fiber composition, and reduced the microbial diversity index of silage. The quality of tropical silage containing $C$. calothyrsus was shown to be good, had excellent fermentation characteristics and the microbial communities were dominated by L. plantarum.

\section{ACKNOWLEDGMENTS}

This research was supported by DIPA of the Research Center for Biotechnology-Indonesian Institute of Sciences and the Japan Science and Technology Agency (JST)/Japan International Cooperation Agency (JICA) as part of the Science and Technology Research Partnership for Sustainable Development (SATREPS). We thank to Japan Collection of Microorganisms-RIKEN BioResource Center for supporting T-RFLP analysis in Japan, and 
Ministry of Research and Technology of Indonesia Government for a graduate scholarship of Doctor Program in Bogor Agricultural University and allowances for a short research in Japan.

\section{CONFLICT OF INTEREST}

We certify that there is no conflict of interest with any financial organization regarding the material discussed in the manuscript.

\section{REFERENCES}

AOAC. 1997. Official Methods of Analysis. Association of Official Analytical Chemists, Arlington, VA, USA.

Arriola, K. G., S. C. Kim, and A. T. Adesogan. 2011. Effect of applying inoculants with heterolactic or homolactic and heterolactic bacteria on the fermentation and quality of corn silage. J. Dairy Sci. 94:1511-1516.

Blackwood, C. B., T. Marsh, S. H. Kim, and E. A. Paul. 2003. Terminal restriction fragment length polymorphism data analysis for quantitative comparison of microbial communities. Appl. Environ. Microbiol. 69:926-932.

Bodas, R., N. Prieto, R. Garcia-Gonzalez, S. Andres, F. J. Giraldez, and S. Lopez. 2012. Manipulation of rumen fermentation and methane production with plant secondary metabolites. Anim. Feed Sci. Technol. 176:78-93.

Cappuccino, J. G. and N. Sherman. 2001. Microbiology; a laboratory manual. $6^{\text {th }}$ Ed. State University of New York, Rockland Community College, NY, USA.

Castro-Montoya, J. M., H. P. S. Makkar, and K. Becker. 2011. Chemical composition of rumen microbial fraction and fermentation parameters as affected by tannins and saponins using an in vitro rumen fermentation system. Can. J. Anim. Sci. 91:433-448.

Cole, J. R., Q. Wang, E. Cardenas, J. Fish, B. Chai, R. J. Farris, A. S. Kulam-Syed-Mohideen, D. M. McGarrell, T. Marsh, G. M. Garrity, and J. M. Tiedje. 2009. The Ribosomal Database Project: improved alignments and new tools for rRNA analysis. Nucl. Acids Res. 37:D141-145.

Deaville, E. R., D. I. Givens, and I. Mueller-Harvey. 2010. Chestnut and mimosa tannin silages: Effects in sheep differ for apparent digestibility, nitrogen utilisation and losses. Anim. Feed Sci. Technol. 157:129-138.

Dubois, M., K. A. Gilles, J. K. Hamilton, P. A. Rebers, and F. Smith. 1956. Colorimetric method for determination of sugars and related substances. Anal. Chem. 28:350-353.

Gómez-Vázquez, A., J. M. Pinos-Rodríguez, J. C. García-López, E. de la Cruz-Lázaro, C. Luna-Palomera, and R. SánchezHernández. 2011. Nutritional value of sugarcane silage enriched with corn grain, urea, and minerals as feed supplement on growth performance of beef steers grazing stargrass. Trop. Anim. Health Prod. 43:215-220.

Hess, H. D., T. T. Tiemann, F. Noto, S. Franzel, C. E. Lascano, and M. Kreuzer. 2006. The effects of cultivation site on forage quality of Calliandra calothyrsus var. Patulul. Agroforest. Syst. 68:209-220.
Iwamoto, K., H. Tsuruta, Y. Nishitaini, and R. Osawa. 2008. Identification and cloning of a gene encoding tannase (tannin acylhydrolase) from Lactobacillus plantarum ATCC $14917^{\mathrm{T}}$. Syst. Appl. Microbiol. 31:269-277.

Jayanegara, A., E. Wina, C. R. Soliva, S. Marquardt, M. Kreuzer, and F. Leiber. 2011a. Dependence of forage quality and methanogenic potential of tropical plants on their phenolic fractions as determined by principal component analysis. Anim. Feed Sci. Technol. 163:231-243.

Jayanegara, A., F. Leiber, and M. Kreuzer. 2011b. Meta-analysis of the relationship between dietary tannin level and methane formation in ruminants from in vivo and in vitro experiments. J. Anim. Physiol. Anim. Nutr. 96:365-375.

Jiménez, N., J. A. Curiel, I. Reverón, B. de las Rivas, and R. Muñoz. 2013. Uncovering the Lactobacillus plantarum WCFS1 gallate decarboxylase involved in tannin degradation. Appl. Environ. Microbiol. 79:4253-4263.

Kaplan, C. W., J. C. Astaire, M. E. Sanders, B. S. Reddy, and C. L. Kitts. 2001. 16S ribosomal DNA terminal restriction fragment pattern analysis of bacterial communities in feces of rats fed Lactobacillus acidophilus NCFM. Appl. Environ. Microbiol. 67:1935-1939.

Kondo, M., Y. Hirano, K. Kita, A. Jayanegara, and H. Yokota. 2014. Fermentation characteristics, tannin contents and in vitro ruminal degradation of green tea and black tea by-products ensiled at different temperatures. Asian Australas. J. Anim. Sci. 27:937-945.

Landete, J. M., J. A. Curiel, H. Rodríguez, B. de las Rivas, and R. Muñoz. 2008. Study of the inhibitory activity of phenolic compounds found in olive products and their degradation by Lactobacillus plantarum strains. Food Chem. 107:320-326.

Li, Y. and N. Nishino. 2013a. Changes in the bacterial community and composition of fermentation products during ensiling of wilted Italian ryegrass and wilted guinea grass silages. Anim. Sci. J. 84:607-612.

Liu, W. T., T. L. Marsh, H. Cheng, and L. J. Forney. 1997. Characterization of microbial diversity by determining terminal restriction fragment length polymorphisms of genes encoding 16S rRNA. Appl. Environ. Microbiol. 63:4516-4522.

Lynch, J. P., P. O'Kiely, S. M. Waters, and E. M. Doyle. 2012. Conservation characteristics of corn ears and stover ensiled with the addition of Lactobacillus plantarum MTD-1, Lactobacillus plantarum 30114, or Lactobacillus buchneri 11A44. J. Dairy Sci. 95:2070-2080.

Magurran, A. E. 2004. Measuring biological diversity. Blackwell Publishing, Malden, MA, USA.

Makkar, H. P. S. 2003. Quantification of Tannins in Tree and Shrub Foliage: A Laboratory Manual. Kluwer Academic Publishers, Dordrecht, The Netherlands.

McDonald, P., A. R. Henderson, and S. J. E. Heron. 1991. The biochemistry of silage. Chalcombe publications. 2nd Ed. Centerbury, UK.

Moss, A. R., J. Jouany, and J. Newbold. 2000. Methane production by ruminants: its contribution to global warming. Ann. Zootech. 49:231-253.

Mulrooney, C. N. and L. Kung Jr. 2008. Short Communication: The effect of water temperature on the viability of silage inoculants. J. Dairy Sci. 91:236-240. 
Norton, B. W. 1994. The nutritive value of tree legumes. In: Forage Tree Legumes in Tropical Agriculture (Eds. R. C. Gutteridge and H. M. Shelton). CABI publishing, UK. pp. 177-191.

Patra, A. K., B. Min, and J. Saxena. 2012. Dietary tannins on microbial ecology of the gastrointestinal tract in ruminants. In: Dietary Phytochemicals and Microbes (Ed. A. K. Patra). Spinger Sciences Business Media, Dordrecht, The Netherlands. pp. 237-262.

Rodríguez, H., J. A. Curiel, J. M. Landete, B. de las Rivas, F. L. de Felipe, C. Gómez-Cordovés, J. M. Mancheño, and R. Muñoz. 2009. Food phenolics and lactic acid bacteria. Int. J. Food Microbiol. 132:79-90.

Sakamoto, M., I. N. Rocas, J. F. Siqueira Jr, and Y. Benno. 2006. Molecular analysis of bacteria in asymptomatic and symptomatic endodontic infection. Oral Microbiol. Immunol. 21:112-122.

Sakamoto, M., Y. Takeuchi, M. Umeda, I. Ishikawa, and Y. Benno. 2003. Application of terminal RFLP analysis to characterize oral bacterial flora in saliva of healthy subjects and patients with periodontitis. J. Med. Microbiol. 52:79-89.

Salawu, M. B., T. Acamovic, C. S. Stewart, T. Hvelplund, and M. R. Weisbjerg. 1999. The use of tannins as silage additives: effects on silage composition and mobile bag disappearance of dry matter and protein. Anim. Feed Sci. Technol. 82:243-259.
Shyu, C., T. Soule, S. J. Bent, J. A. Foster, and L. J. Forney. 2007. MiCA: a web-based tool for the analysis of microbial communities based on terminal-restriction fragment length polymorphisms of $16 \mathrm{~S}$ and $18 \mathrm{~S}$ rRNA genes. Microb. Ecol. 53:562-570.

Sonja, N. H., S. D. Martens, P. Avila, and S. Hoedtke. 2012. The effect of inoculant and sucrose addition on the silage quality of tropical forage legumes with varying ensilability. Anim. Feed Sci. Technol. 174:201-210.

Steurm, C. D., T. T. Tiemann, C. E. Lascano, M. Kreuzer, and H. D. Hess, 2007. Nutrient composition and in vitro ruminal fermentation of tropical legume mixtures with contrasting tannin contents. Anim. Feed Sci. Technol. 138:29-46.

Tiemann, T. T., C. E. Lascano, H. R. Wettstein, A. C. Mayer, M. Kreuzer, and H. D. Hess. 2008. Effect of the tropical tanninrich shrub legumes Calliandra calothyrsus and Flemingia macrophylla on methane emission and nitrogen and energy balance in growing lambs. Animal 2:790-799.

Van Soest, P. J., J. B. Robertson, and B. A. Lewis. 1991. Methods for dietary fiber, neutral detergent fiber, and nonstarch polysaccharides in relation to animal nutrition. J. Dairy Sci. 74:3583-3597.

Wanapat, M., S. Kang, P. Khejornsart, R. Pilajun, and S. Wanapat. 2014. Performance of tropical dairy cows fed whole crop rice silage with varying levels of concentrate. Trop. Anim. Health Prod. 46:185-189. 